\title{
Heroes, villains and victims: agricultural subsidies and their impacts on food security and poverty reduction
}

\author{
Andrew Dorward, SOAS, University of London \\ Jamie Morrison, Food and Agriculture Organization ${ }^{1}$
}

\begin{abstract}
:
Subsidies have been a pervasive feature of agricultural policy in both high and low income countries. This chapter describes different kinds of subsidies and reviews evidence on their economic, food security and poverty impacts. The evidence suggests that different subsidy programmes have had in some contexts profoundly positive and in other contexts profoundly negative impacts on food security and on the livelihoods of poor people and poor societies. Discussions of the historical and potential roles of subsidies and their more recent use have, however, been the victim of an unhealthy over-emphasis on their negative effects without sufficient consideration of the potential to overcome these. These issues need to be addressed if agricultural subsidies are to fulfill their potential to make a significant contribution in addressing continuing and emerging challenges to food insecurity and poverty.
\end{abstract}

${ }^{1}$ Disclaimer: the views expressed in this chapter are those of the authors and do not necessarily reflect the views of the Food and Agriculture Organization of the United Nations 


\section{Introduction}

This chapter reviews evidence on the food security and poverty impacts of different agricultural subsidies in developed and developing countries. The two main parts of the chapter examine historical experience and theoretical analysis first of developed country subsidies' and then of developing country subsidies' impacts on food security and poverty, in developing countries. We conclude by considering possible implications of current and emerging issues for agricultural subsidies in the future. First, however, we clarify what agricultural subsidies are, distinguish between different types of agricultural subsidy, and outline their basic impacts.

Building on McCulloch et al. (2001), Meyer (2011) and World Bank (2007) we define agricultural subsidies as

'payments by governments to (or reduction in payments from) private individuals or organisations to offset agricultural costs or raise or lower agricultural prices in the stated pursuit of the public interest (such as overcoming a market failure, increasing productivity and/or transferring resources to a particular economic, social or political group)'.

Key elements of this are the transfer of resources from government to private individuals or organisations (as compared with the situation without subsidies) and (at least stated) pursuit of the public interest.

Agricultural subsidies are, however, only part of a wider set of support measures which governments may use to pursue the same ends without the direct transfer of resources from government (and indirectly taxpayers) to beneficiaries. Other forms of support normally involve transfer of resources from buyers to sellers as a result of price changes caused by regulations or market interventions. Prices may be raised by import restrictions or export promotion. However the distinction between subsidies and other forms of support is often blurred, as subsidies commonly affect suppliers and buyers through price changes as well as by direct expenditure transfers from government.

We therefore broaden our focus in this chapter to consider other forms of agricultural support alongside subsidies, and identify three types of basic agricultural producer support ${ }^{1}$ :

- Output price support, where intervention prices, import restrictions (quotas, or tariffs), or export promotion (subsidies) raise domestic prices, with a transfer from consumers to producers, welfare losses for consumers (who pay a higher price and consume less) and welfare gains for producers (who receive a higher price for a greater amount of production). The cost to government is the loss on disposal of surplus production plus administration costs.

- Output price subsidies to producers or consumers, which raise prices received by producers and/or lower prices paid by consumers. Both consumers and producers gain from increased quantity consumed and produced, while consumers benefit from paying lower prices and producers benefit from receiving higher prices. Government cost is the difference between consumer and producer price for the entire quantity traded, and it must maintain differential consumer and producer prices. Unless the subsidy overcomes some market failure inhibiting supply, total consumer and producer gains are less than total cost to government, the difference being the 'deadweight loss' (Siamwalla and Valdes, 1986). Relative impacts on producers and consumers depend on commodity and market characteristics and context, principally 
demand and supply elasticity and global market engagement, with the import parity (plus import taxes or less subsidies) a maximum price, and export parity (plus export subsidies or less taxes) a minimum.

- Production subsidies, for example credit or input subsidies, which lower production cost with impacts analogous to those of producer price subsidies (see Dorward (2009) for further elaboration).

The impacts discussed above are the static effects of subsidies. Dynamic effects (for example in changing productivity, behaviour or the structure of markets and economies) are of much greater interest in development for their effects on wider growth. We discuss these later.

Agricultural support to producers may also take many forms. Apart from output price interventions, common distinctions are made between public investments (investments in public goods such as infrastructure, research, or market development, services or regulation and standards), private investment subsidies (grants for private infrastructure, research or extension facilities), and private subsidies (such as for inputs or credit). The distinctions between these are often blurred.

\section{Impacts of developed economy subsidies on development, food security, and poverty in developing countries}

\subsection{Introduction}

The relationship of developed country agricultural support with economic, food security and poverty indicators in developing countries is complex. This complexity has contributed to a highly divisive and often unsubstantiated debate on the implications of the continued use of these policy instruments.

In simplistic terms, subsidies, to the extent that they provide incentives to producers to increase production, impact on agricultural trade balances, either by reducing the import requirements of, or by increasing levels of exports from, the subsidizing country. This results in an increase in excess supply on global markets and, where there are no demand shifters and there is a substantial increase in excess supply from one or more subsidising countries, reduced global prices. These reduced global prices have potential impacts on import and/or export prices for all countries, affecting domestic market prices and the returns to producers and expenditure of consumers. This in turn, impacts development related indicators.

In this section, we proceed by breaking down the relationship along the components highlighted above. First we consider evidence on the extent to which agricultural subsidies provide production incentives and then on ways that resulting increases in production might translate into reductions in global market prices. These components, although by no means simple, are probably the easiest components of the relationship to assess.

It is then necessary to determine the implications of changes to global prices on, for example, food security indicators in developing countries. Here one must consider questions such as:

i. the extent to which global market prices are relevant to the country in question - are these the prices at which the country imports, or is paid for its exports? What are the implications of international market structures (multinational corporations, contractual arrangement between governments, the significance of futures markets etc)? 
ii. is the relationship between a price fall for an exporter the same as for a price rise (i.e. will current market access conditions allow the development of new market opportunities for increased production?);

iii. how does a change in transmitted domestic price play out for different segments of the population? (for example for a food commodity, - how are urban consumers, rural net producers, and rural net consumers affected, when each of these groups is highly heterogeneous with differential expenditure patterns and supply responsiveness?);

iv. how do market price impacts play out in terms of household food security?

The fourth part of this section touches on a number of these issues, highlighting the increasingly tenuous and context specific nature of the relationship. It also draws these questions together to demonstrate that in some cases there appears to be a direct and negative causal relationship between agricultural subsidies in developed countries and indicators of interest in developing countries (e.g cotton), in other cases food security and poverty impacts are likely to be small (e.g dairy), while developed country subsidies for some food staples may produce significant short and long run development and welfare impacts, but these can differ significantly both in magnitude and direction across different developing countries.

\subsection{The production and trade distortive effects of agricultural subsidies}

\section{Changing roles and perceptions of agricultural subsidies}

In eras of depressed global prices, subsidies provided to the agriculture sector in many OECD countries were often attacked as causing excess production and reduced global prices which reduced incentives to agricultural production in non-subsidizing countries, undermining poor producer incomes and both public and private sector investments required to facilitate the adoption of productivity enhancing technology.

The post 2008 context of higher global food prices (with associated demand shifters such as biofuel mandates) requires a rethinking of these arguments and of the roles agricultural subsidies might play in a scenario where attention is now increasingly on the ability of global agriculture to achieve a 60\% increase in production by 2050 (OECD-FAO, 2012)).

Changing patterns of agricultural support also require some rethinking of these issues, although the implications of new forms of agricultural support may not be as great as is sometimes thought. In the past, agricultural subsidies were responsible for a relatively small proportion of overall agricultural support in OECD countries (in 1986 for example, $80 \%$ of total OECD support was provided through market price support mechanisms). Since then radical changes in agricultural policies and significantly higher global prices (reducing the gap between target prices and global prices and hence the need for market price support) have together led to dramatic increases in the importance of subsidies as a proportion of total support.

Changes in the form of support are illustrated well by trends in the EU from 1986/8 to 2008. Total support in this period remained relatively stable at Euro 80bn - Euro 90bn per annum. However, so called Amber box support (measures that are defined as trade distorting under the WTO Agreement on Agriculture or AoA) fell to Euro 11.8bn in 2008, less 
than half their value in 2006-07 and only 20\% of the proportion in 1986/8. "Minimally trade distorting" payments (defined as Green Box payments under the WTO AOA) increased significantly to Euro 63 bn (of which, most significantly, Euro 32bn is provided as decoupled support, Euro 7.7bn in investment aids, and Euro 5.7bn in environmental payments). The shift towards greater use of "decoupled payments", has been associated with a shift towards mechanisms of support that are perceived to be less trade distorting.

Changes in the scale of support occurred most markedly after 2008, typically the result of countercyclical payments declining as a consequence of high world prices or from shrinking disaster payments. Thus actual budgetary support payments of OECD countries fell between 2008 and 2010, with total OECD member states spending of $\$ 227$ bn in 2010 down 6\% from 2009 and 13\% from 2008 (Financial Times, 2011).

There have therefore been significant changes in the ways in which many developed countries provide support to their agriculture sectors, with a reduction in the use of subsides coupled to the production of specific crops and an increase in the use of policies which are deemed to be less production and hence trade distorting.

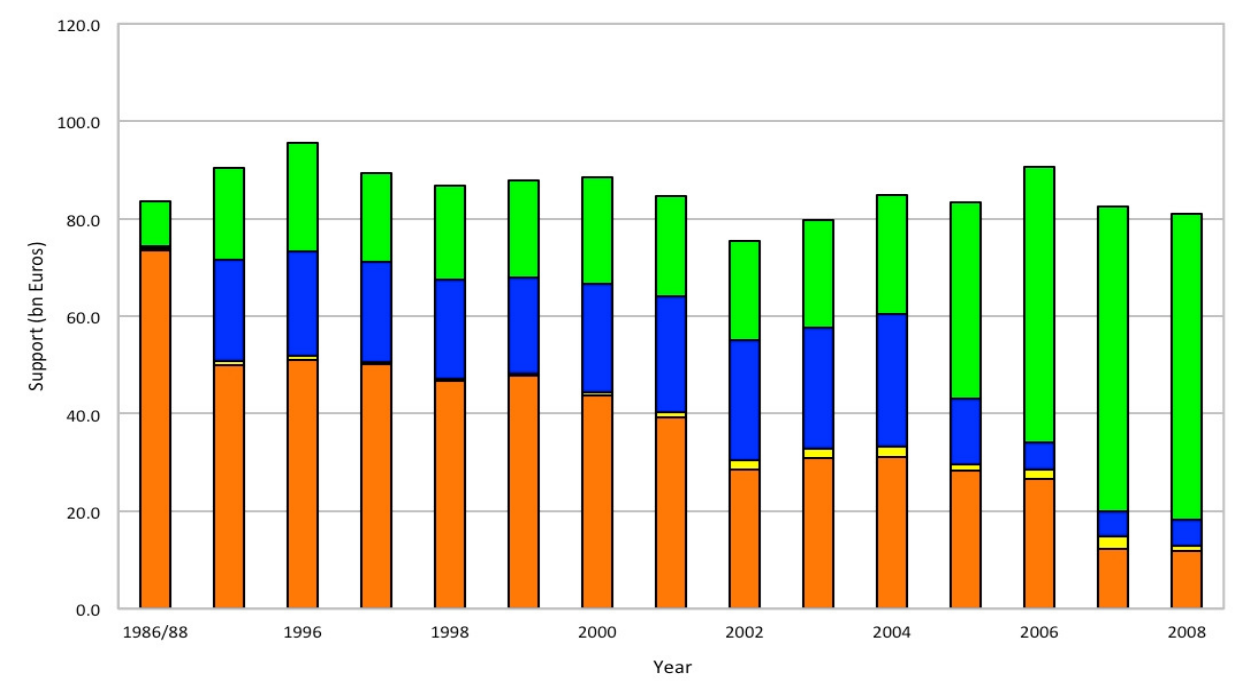

Figure XXX.1 - Shifts in support to EU producers

Source: ICTSD (2012)

\section{Production impacts}

Despite these change in support provided to OECD agricultural producers, however, limited falls in the total value of support and debate about the extent to which new forms of subsidy payments are less distortionary of production and trade, lead to questions about the overall production and trade impacts of these policy reforms ${ }^{2}$.

The OECD secretariat has made substantive contributions to the literature on decoupled support, both in terms of the development of conceptual frameworks and in empirical analysis of the degree of decoupling of various support measures (OECD, 2004).

Their hierarchy of distortiveness is based on the price effects of the different policies, that is, how the expenditures on policies affect the relative prices of inputs or outputs and how this in turn is projected to impact on production levels. In general, the conclusion is that 
payments to inputs are most distortive, followed by payments to output, payments based on crop area and finally payments based on historical entitlements.

There are, however, also a number of non-price effects that could potentially affect the hierarchy. These include the effect of these policies on the level of risk facing producers, the incentives and constraints to taking resources out of production, the ease of policy enforcement and its propensity to change, and the effect of individual policy instruments when implemented in combination with other policy instruments. We consider these in turn.

Risk affects decisions on land allocation and input use intensity in production. Fixed payments reduce risk by acting as a form of insurance which affects the distribution of possible prices facing the producer, ensuring that producers cannot receive returns below a certain level. With reduced levels of risk and increased wealth, producers may be prepared to invest more resources in the production of crops for which the uncertainty in relation to future price, revenue and/or yields would otherwise be greater (Hennessy, 2004). Crop insurance schemes can also distort relative incentives for the production of different crops and they are also production distorting in the sense that they encourage increases in aggregate production. There are related questions and considerable uncertainty over what happens to marginal areas with decoupled payments. It is possible that in some situations decoupling may not impact the average net revenue facing all producers, but could impact the distribution of net revenue if such policies result in reallocation of support away from larger more efficient farms towards smaller and more marginal enterprises. This could result in relative increases in returns to the latter set of farmers, with possibly more marginal land being drawn into production as a result of increases in net revenue of these smaller producers.

Furthermore, while replacement of 'production enhancing' subsidies by decoupled support may encourage some producers to exit farming, the land that they farm, with few uses outside agricultural production, is likely to continue to stay in production, but be transferred to other producers. Thus although the number of farmers in the OECD countries is falling, the level of resources committed to farming is not: production levels in the OECD continue to increase despite the greater use of "decoupled" support.

One difficulty in ranking policy categories with respect to their trade distortiveness is that actual impacts depend not only on the type of policy in place, but on the way in which it is designed and enforced or implemented in practice. Impact is often highly policy-specific and so it is difficult to know in advance how this affects the ranking of measures as regards the degree of decoupling. Key dimensions include enforcement, and expectations of future assistance and of updating of base payment parameters.

The distortive nature of a policy is also affected by the whole policy set of which it is a part. Analysts generally hold that production impacts can be very different when a combination of policies work together as compared with the effects of separate individual policies. Unfortunately, however, there is little empirical work on individual farmer reactions to different types of payments when multiple policy effects are taken into account. ${ }^{3}$

Overall, a review of contemporary literature by Skully (2009) suggests that given the above determinants of production distortiveness, production impacts of changes in support tend to be observed where recipient households have low incomes or cannot obtain credit. Production impacts in OECD countries are therefore relatively low, given that the share of OECD output by such households is small - indeed, most farmers are wealthier than the 
average household. He suggests, however, that decoupled policies could have substantial production effects where credit markets and supply chains are under-developed, for example, had they been used in the 1950s, or in contemporary developing countries.

\subsection{Implications for Global market indicators}

The discussion above suggests that alternative support measures and hence policies emphasising these may have had impacts on production, but that the magnitude of the impact is often difficult to discern. Where there have been impacts, then the extent to which this affects global prices is also uncertain, depending upon a number of factors, such as the size of the production increase relative to market size and the elasticity of demand.

Methodological approaches to estimating the impact of subsidies (or their reform) on global market prices often struggle to find estimates of these effects. FAO (2006b) provide a critique of alternative trade policy simulation models, concluding that although most approaches do not adequately distinguish between subsidies and support in general, commodity based partial equilibrium models are probably most useful for the determination of price impacts. Even so, studies using apparently similar approaches often generate widely divergent results with the assumptions made significantly affecting the results, even for relatively straightforward scenarios such as the reduction of OECD subsidies on cotton production, for example. Here contemporary studies unambiguously demonstrate that the removal of domestic subsidies in industrialized countries would reduce cotton production in, and exports from, these countries, but there is significant divergence in the estimated magnitude of this impact on global prices, with studies estimating increases of between 2 and 35 percent as a result of the removal of subsidies. Similar divergences are found in studies of the reform of rice policies (10 - 29\%) (FAO, 2006a) and dairy policies (10-20\% ) (FAO, 2005a). Such estimates are also time bound, given significant shifts in the structure of trade. According to Matthews (2012), for example, world cotton prices are now more distorted by subsidies in China and Turkey than by support provided by the EU or US.

\subsection{Translating global market impacts to the national level impacts on developing countries}

Linking global market impacts to impacts at the national level is more problematic still. For trade balances, the extent of short term impacts from an increase in the global market price can be considered in terms of changes in net export revenues or food import bills. If a country is an exporter of food and/or non-food agricultural commodities, it is assumed to benefit but if it is a net food importer, it is assumed to be negatively impacted. In the longer term, the impact will also be affected by the country's capacity to increase levels of agricultural production in response to higher domestic prices.

Konandreas (2012) provides an interesting analysis of the drivers of recent increases in food import bills across different least developed countries by separating the effects of increases in unit import prices from the effects of increases in volumes of net imports. Whilst in some countries the price effect dominates, increased volumes of imports have been as (if not more) important than price increases in the majority. Changes in trade balances also have wider macro-economic impacts, and these interact with the effects of import/ export prices on domestic prices, mediated by fiscal and other effects of domestic policy responses (Dorward, 2012). For net food importers high food prices tend to increase import bills, adversely affecting the balance of payments and putting downward pressure on domestic currency, restricting availability of foreign exchange for other imports or 
depressing the value of the local currency which then raises the local price of imports (leading to a further increase in domestic prices of imports) with wide ranging impacts in the domestic economy. The opposite effects are experienced by food exporters or by food importers experiencing food price falls. Fiscal impacts of food price changes are then associated with existing taxes or subsidies on imports or exports, the nature of these (whether they are fixed per tonne or ad valorem) and any changes in response to political or fiscal pressures (which often pull in opposite directions). Any transmission of changes in international prices to consumers also affects inflationary pressures, which in turn affect income distribution between and costs for different sectors and social groups, with further impacts on foreign exchange rates, interest rates and other macroeconomic variables.

At the household level, the patterns of impacts are more varied still. FAO (2003) and Thomas (2006) proposed a methodology for examining the impacts of trade and related policy reform which provides a basis for considering the implications of border price changes that might result from a reduction in OECD subsidies on food security indicators. In a first stage, a set of factors determine the extent to which increases in global prices are transmitted to domestic producers and the extent to which they respond. These factors include, inter alia, the level of institutional development, the functionality of markets, access to productive assets, and taxes and subsidies ${ }^{4}$. A second set of factors determines the extent to which any increase in production of a given commodity impacts at the local economy and household levels. At the household level, these factors include household dependency structure, location, asset structure, food expenditure patterns and sensitivity to price and other non-price information.

The multitude of factors and the context specificity in which they are found makes it all but impossible to delineate a straightforward generic relationship between global market impacts and the indicators of relevance to a country. Trade simulation models have been found wanting in shedding light on the question. While partial equilibrium models provide some indication on global market price effects, the models tend not to be sufficiently disaggregated to adequately capture the vast heterogeneity in developing country characteristics.

Differences in the estimated impacts and implications of changes in global market indicators vary significantly across commodity types. Traditionally, the white commodities cotton, dairy, rice and sugar - have received the most significant levels of support, albeit provided through quite different regimes. Trade simulation models demonstrate that the impacts of these policies have been distortive of world market prices, but the implications of these distortions for developing countries are likely to differ markedly across commodities.

For cotton, an export commodity for most producers, particularly those in poorer developing countries, the implications are relatively clear. A reduction in the global price reduces export revenue for the exporting country, and to the extent that prices are transmitted to producers, reduces both incentives for production and producer incomes, with large negative impacts on poor cotton producing communities in low income countries.

For dairy, it is the more competitive exporting countries (including New Zealand and the Southern Cone countries of Latin America) who have been penalized by depressed prices. The positive impacts of increased prices following a reduction in support would be likely to be concentrated in these countries, with importing countries facing increased milk import bills. The global dairy market is, however, very much a residual market, with most countries close to self-sufficiency, so impacts on poor consumers and on food security are likely to be small. 
For food staples such as rice, the implications of a reduction in developed country support are less clear. On the basis of results from trade simulation models, it was often argued that the estimated price increases resulting from policy reforms in developed countries would incentivize producers in developing countries, offsetting any consumer losses resulting from increased domestic prices. The net effect for food importing developing countries was generally ambiguous in these models depending very much on the assumed responsiveness of producers to increased prices.

Episodes of rapid price increases over recent years provide some clues as to the potential implications of an increase in global prices that could result from a reduction in OECD support. Higher food prices have had significant short term negative implications for consumers in many developing countries, but have not generated a noticeable supply response from developing country producers ${ }^{5}$. FAO (2013 (forthcoming)) argue that the mismatch between expectations of positive supply response and the actual response has much to do with a limited understanding of the propensity of smallholder producers to respond. Smallholders are a very heterogeneous group and the determinants of, and constraints to, their responsiveness vary greatly across households and the contexts in which they operate. Debates about the impacts of more recent high food prices both question earlier arguments about the benefits of policies reducing support and raising prices, and illustrate the complexity of determining winners and losers from higher food prices (Dorward, 2012; Dorward, 2013 (forthcoming); FAO, 2013 (forthcoming); Swinnen, 2011)

\section{Impacts of agricultural subsidies in developing countries ${ }^{6}$}

\subsection{Introduction}

As with developed country subsidy impacts, examination of the impacts of developing countries agricultural subsidies on food security and poverty reduction is complex, contested, and context specific. We try to unpick this in three different contexts and phases: 'successful Asian green revolutions', 'post green revolution Asian situations', and 'current pre-green revolution sub Saharan Africa situations'. We examine subsidy implementation and its context and evidence on subsidy impacts for each case, and then theoretical and analytical understanding of subsidy impacts.

\subsection{Policy and practice}

Emerging understanding of the contribution of agriculture to wider development in the 1960s (for example Johnston and Mellor, 1961; Mellor, 1966) fed into and was fed by promotion and successes with the 'Green Revolution' in Mexico and in parts of Asia. This involved national government commitments to increasing agricultural production with a range of investments in irrigation, agricultural research and extension, agricultural credit services, agricultural input subsidies, and price subsidies or price support, all of which were intended to increase production from irrigation and increased inorganic fertiliser on new high yielding rice and wheat varieties (Djurfeldt et al., 2005; Dorward et al., 2004b; Economist Intelligence Unit, 2008; Hazell 2009).

The effects of the green revolution in Mexico and Asia are much debated (Lipton and Longhurst, 1989). Increases in production of staple cereals (wheat and rice) are not generally disputed. However initial reports that larger farmers were benefiting more than smaller farmers were superseded by later studies that showed that small farm adoption rates often caught up, and they also adopted on a greater proportion of their land. Nevertheless large farmers did gain innovators' (first adopter) benefits, and uptake was restricted to particular 
crops (wheat, maize, rice) in more favourable conditions (irrigated or good rainfall areas with good soils). Continuing concerns that more wealthy, male, owner occupiers tended to benefit at the expense of the poor, tenant farmers, women and the landless were partly explained by increasing uptake of mechanization. This was supported by widespread machinery subsidies as some types of mechanization clearly replaced labour and benefited more wealthy landowners at the expense of often poorer often female landless labourers (although other types, such as groundwater pumps, expanded labour demand in crop production, harvesting and processing). Lipton and Longhurst (1989) distinguish between the labour displacing effects of machinery subsidies, and increased labour demand and productivity as a result of green revolution technologies. These, they argue, clearly benefited poor rural people, and rising incomes stimulated demand for non-farm employment. As a result Hazell (2009) reports that between 1976 and 1995 poverty incidence in Asia roughly halved and the number of poor people fell by roughly $30 \%$ although population increased by $60 \%$. We report below (in FigureXXX.3(b)) estimates of poverty reduction in India directly attributable to green revolution investments (Fan et al., 2007). As regards food security, Rosegrant and Hazell (2000) estimate that Asian cereal yields grew by $3.13 \%$ per year from 1967 to 1982 , and production grew by nearly 3.6\% per year, with an overall production increase of nearly $70 \%$ in the 15 year period and lower cereal prices and an increase of nearly $30 \%$ in per capita food and calorie availability from 1970 to 1995 . There are, however, concerns about the effects of intensive water, fertiliser and pesticide use on water availability, on soils, and on pest build ups. While technologies that address these problems exist, their uptake is partly inhibited by fertiliser and irrigation (power) subsidies. Hazell (2009) also notes that these environmental concerns need to be considered in the context of major environmental benefits from increased food production from much smaller areas of land, reducing agricultural pressure on forests and on more marginal and fragile land.

The immediate impacts of 'successful Asian green revolutions' on poverty and food security appear to be clear, but isolation of the particular contribution of credit, fertiliser and irrigation subsidies is difficult: 'attempts have been made to assess separately the contributions of the different components of the Green Revolution package, but in practice it was the powerful interactions among these individual components that made the difference. Only with all of these components in place did farmers- particularly small farmers - have the economic incentive to adopt the new packages.' (Hazell 2009 p 25). Fan et al. (2007) however use empirical evidence from India to estimate, across different states and decades, the returns in agricultural GDP from government expenditures. They divide these expenditures between investments (separating roads, education, irrigation infrastructure, and agricultural research and development) and subsidies (separating fertiliser, credit, irrigation and power). The results are shown graphically in figure XXX.2 Dorward et al. (2004a) use these results to test hypotheses regarding positive and negative returns to different investments and subsidies. Overall there is strong evidence of very favourable returns to investments in roads, education, and agricultural research and development, and to a lesser extent to irrigation investments (though marginal returns decline for education, roads and irrigation investments but, with the exception of irrigation investments, are still favourable). Returns to spending on operational subsidies are lower than on investments in roads, education, and agricultural research and development. However for subsidies on irrigation, credit and fertiliser these were positive in the earlier years of the green revolution but then declined. Similar patterns are observed in analysis of impacts of different investments and subsidies on poverty reduction except that for the first three decades 
returns to credit subsidies are second only to returns to road investments, and returns to irrigation and fertiliser subsidies are close to those from education and agricultural research and development (figure XXX.2(b)).
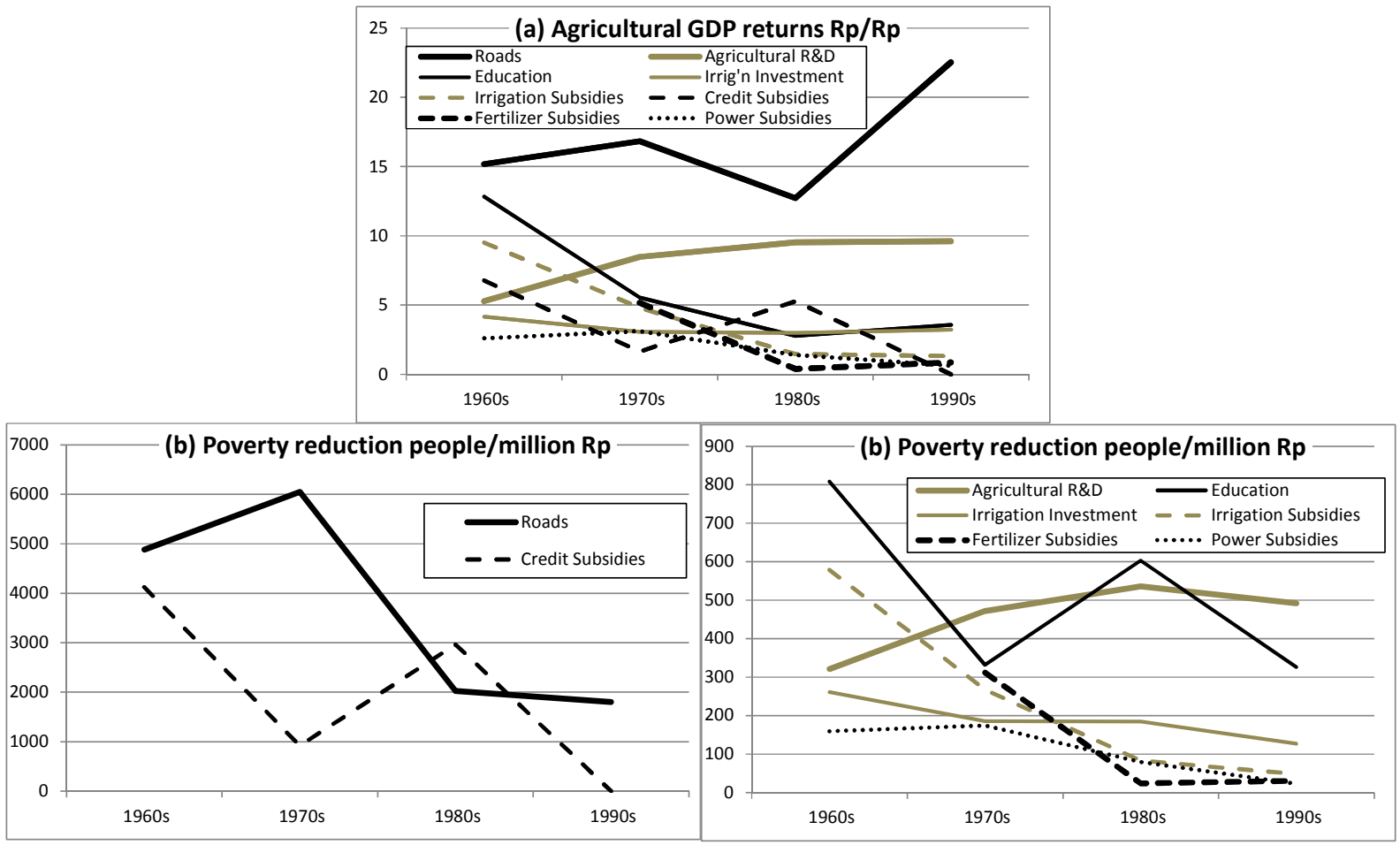

Figure XXX.2 Agricultural GDP and poverty reduction returns to Indian government spending, $1960 \mathrm{~s}$ to $1990 \mathrm{~s}$

Fan et al. (2007). "n.s" plotted as 0.

Despite the success of the state-led Asian Green Revolutions in the 1960s and 70's, the 1980s saw international development policy turn away from these models to 'Washington consensus' reliance on liberalised markets and specific redirection of public spending away from subsidies (Williamson 1989). This may be attributed to three main influences: the ascendance of neo-liberalism with pursuit of market solutions and rolling back of the state, particularly in the US and UK; increasing recognition of problems with state intervention in growing economies in Asia; and widespread recognition of problems with ineffective, unsustainable and indeed often counter-productive state intervention in Africa.

Washington consensus scepticism of agricultural subsidies is supported by analysis of the efficiency and effectiveness of continuing agricultural subsidies in post-green revolution Asian countries (see for example Rashid et al. (2008), Wiggins and Brooks (2012) and the declining returns to subsidies in India reported by Fan et al. (2007)). Apart from environmental problems with intensive use of water and fertiliser encouraged by power and fertiliser subsidies, subsidies were seen to either offer negative economic returns or lower returns than public investments in agriculture.

These arguments were perhaps developed most strongly with regard to agricultural credit subsidies, with subsidies provided through agricultural banks and other state organisations widely considered to have been ineffective, expensive and unsustainable (Adams et al., 1984; Von Pischke et al., 1983). Recognition of these failings led to them being largely discredited" and "A new financial systems paradigm emerged that shifted the 
emphasis from dispersing cheap credit to creating sustainable institutions" (Meyer, 2011, p5). Interest then turned to microfinance approaches, emphasising institutional sustainability and investment in institutional development rather than subsidies on operations. However microfinance programmes have faced increasing criticism of lack of evidence of benefits to the poor (Bateman, 2012; Helmes and Lensink, 2011), alongside long standing concerns about limited engagement in agricultural finance (Meyer, 2011), with many of microfinance's features being unsuitable for supporting intensification of staple crop production in poor areas (Morduch, 1999; Poulton et al., 2010) despite the critical role this plays in food security and poverty reduction.

With regard to Africa, agricultural subsidies were identified as a major element in inefficient and fiscally and economically unsustainable policies undermining private sector services growth, distorting market incentives, and blunting competitiveness and farmer incentives (World Bank, 1981): inherent subsidy inefficiencies, inefficient implementation and diversion led to very limited benefits to farmers and indeed net costs. We note, however, that there were African countries (for example Zimbabwe, Zambia, Kenya and Malawi) that implemented subsidy systems that, with other interventions, had initial success in raising productivity but for varying political and economic reasons (amongst them inefficient implementation and the withdrawal of donor support) failed to either maintain the fiscal investment and market systems needed for sustained benefits, or develop unsubsidised alternatives (Smale and Jayne, 2009).

Dorward et al. (2009) note that across these Asian and African experiences there are major examples of both failures and successes of subsidies within state led approaches to smallholder staple crop development - but there are very few examples of success in private market led approaches (Kenya's mid 2000s growth of smallholder fertiliser use is a notable exception (Ariga et al., 2008)). Here, however, the failures have been less obvious -a failure to invest rather than investment failures - and resultant continued food insecurity and poverty are less easy to attribute and less obvious than macro-economic and parastatal problems from failed government investments. It can also be argued that private market led approaches have not been tried properly as for political reasons it has been very difficult to consistently implement liberalisation of staple food chain markets. This, however, may itself be seen as a major challenge to private market led approaches (Tschirley and Jayne, 2010).

Turning now to consider 'current pre-green revolution sub Saharan Africa situations', liberalised policies' apparent failures in promoting sustainable staple food crop intensification in the 1980s and 1990s led to increasing concern among African politicians, NGOs and some policy analysts. This was accompanied by continuing political demands for fertiliser subsidies (which had continued to some extent in a few countries), donor tensions in responding to these demands (with differing views on subsidies' merits and on growing democratic legitimacy among African governments), concerns about soil fertility and rural stagnation and poverty in Africa, and consideration of input subsidies as potential social protection instruments. These concerns led to consideration of potential new roles for input subsidies in promoting short term private input market development, replenishment of soil fertility, social protection for poor subsidy recipients, and national and household food security (Morris et al., 2007).

Consideration of these potential new roles was accompanied by interest in new approaches and instruments for delivering input subsidies, so called 'smart subsidies'. Like earlier alternative approaches to credit system development, these emphasised the development of sustainable input supply systems, as shown by 10 features of smart 
subsidies described by Morris et al. (2007): promoting fertiliser as part of a wider strategy and market based solutions and competition in input supply; paying attention to demand and economic efficiency; empowering farmers; and pursuing regional integration, sustainability, pro-poor economic growth and an exit strategy; with precedence for poverty reduction or food security over efficiency and sustainability goals only in exceptional circumstances (op.cit, p103-105). Smart subsidy instruments include vouchers, targeting, rationing, loan guarantees, demonstration packs, and matching grants.

Reviews of the limited number of studies of input subsidies adopted in Sub Saharan Africa countries after 2005 suggest that interest in getting input subsidies to serve new functions and objectives, and their cost effectiveness in this, continue to be controversial (Chirwa and Dorward, 2012 (forthcoming); Druilhe and Barreiro-Hurlé, 2012). Despite substantial variation in some aspects of the programmes reviewed, it appears that:

- They address important social, economic and political issues

- There is relatively limited available information on the implementation and outcomes of most programmes

- There is a strong prevalence of heavy subsidy rates ( $50 \%$ or more), of rationing and of often problematic targeting

- Most focus on production, food availability and producer welfare objectives, with less attention to food security, consumer welfare and wider pro-poor growth

- There is limited integration with complementary public investments or promotion of soil fertility,

- Many programme have mixed impacts on private sector suppliers, with limited attention to private sector input supply development

- Effective programme implementation (with better entitlement systems, targeting, and evaluation) and 'exits' or 'graduation' also receive limited attention.

Chirwa and Dorward, 2012 (forthcoming)) conclude that 'the mixed record of input subsidies continues', with some programmes leading to clear increases in food production but a general lack of sufficient evidence to make robust judgements about clear food security and poverty reduction benefits. Their examination of the Malawi input subsidy programme from 2005, for example, concludes that there is strong evidence for increased production and positive economic returns, but mixed evidence on food security and poverty reduction gains: some analysis suggests clear gains from the programme while other data show little or no gains. They note, however, considerable scope for improving impacts through better implementation and integration with complementary policies.

\subsection{Changing thinking on subsidies in agricultural development}

Following Chirwa and Dorward's observation of input subsidies' 'mixed record', we now turn to consider how theoretical analysis and thinking on agricultural development subsidies have evolved since the 1960 s.

Initial analysis focused on ways in which these could make adoption of new technologies more attractive to smallholder farmers (Ellis, 1992). Producer subsidies increased returns or reduced input costs and thus increased profitability and reduced farmers' perceptions of risks (from their limited knowledge of technology use and/or benefits). Complementary input, credit and extension services were supposed to help farmers adopt new technologies and quick learning of benefits and skills would mean that subsidies could be quickly phased out. 
This rationale drew on standard economic analysis of producer subsidies shifting farmers' supply curves for agricultural produce, addressing market failures caused by differences between farmers' and societies' perceptions of the benefits, costs and risks of adopting new technologies. Specific examples of these divergences include farmers' lack of knowledge about the benefits of technical change, their need to learn how to implement it effectively (Crawford et al., 2006; Ellis, 1992; Morris et al., 2007), high private costs of working capital, or high risk perception and aversion in investing in production. The first two divergences (between farmers' and society's costs, benefits and perceptions) effectively provide an infant industry argument for subsidies as the divergences should decline with experience. The latter two divergences may decline with increasing farm productivity, wealth and market development. Either way, the benefits from subsidies should be relatively short lived.

Arguments for subsidies' temporary role were, in effect, temporary arguments. As subsidies tended to persist after the green revolution had 'taken off', so analysts became increasingly critical of them: both theory and empirical observation suggested that the effective implementation of subsidies faced a number of difficulties, and these difficulties became increasingly obvious.

First, simple economic theory suggests that if subsidies are not addressing and overcoming significant market failures then they incur deadweight losses which actually reduce welfare. One cause of this is that once farmers recognise the true value of a technology and of productive inputs then subsidies lead to over-production and over-use of inputs (beyond economic optima). Subsidies also incur costs with little benefit if the subsidy does not lead to increased production by target beneficiaries, because they are poorly implemented of if beneficiaries face other critical constraints which are not being addressed.

Second, transfers to producers can be analysed in terms of inefficiencies associated with economic 'rents'. These arise in three ways. First, part of a general subsidy goes to production that would occur even in the absence of a subsidy. Second, producer transfers often bid up demand for agricultural land and labour, and may then be passed back to owner of these factors of production ${ }^{8}$. Finally, official or unofficial rationing of subsidies may give opportunities for politicians, government officials, fertiliser suppliers, farmer organisation office bearers or other controlling subsidy access to divert subsidies from their intended beneficiaries for a side payment or to demand payments from beneficiaries.

Another difficulty with subsidies concerns leakages and diversion away from their intended use. This arises in three main ways: diversion from intended (targeted) beneficiaries because it is often difficult to channel subsidies to particular types of farmers; diversion across agricultural products away from those yielding the highest social returns; and cross border leakages, when subsidy benefits are captured outside the country.

Recognition of these theoretical and practical difficulties with subsidies led to increasing emphasis of economists and northern policy analysts on difficulties with input subsidy programmes. This also emphasised problems with cost control, inefficiency and sustainability due to

- political pressures for the expansion of subsidies, and only weak pressures for their control.

- political resistance to scaling down or termination of subsidies.

- regressive benefits favouring larger farmers.

- market distortions which crowd out and inhibit private sector investment and hence impede sustainable development. 
These concerns led to conventional wisdom among economists and international donors in the 1980s and 90s that agricultural subsidies were largely ineffective and inefficient policy instruments that contributed to government over-spending and fiscal and macro-economic problems.

From the mid 1990s, however, this conventional wisdom was increasingly challenged. Resurgent interest in agricultural input subsidies in particular in Africa, as discussed earlier, together with reappraisal of the historical roles of subsidies in Asian green revolutions led to new thinking about their potential roles.

Dorward et al. (2004b), for example, postulated that there are necessary conditions for intensive cereal based transformations: appropriate, high yielding agricultural technologies; local markets with stable output prices that provide reasonable returns to investment in 'improved' technologies; seasonal finance for purchased inputs; reasonably secure and equitable access to land; and infrastructure to support input, output and financial markets. They observed that these conditions (which might be more easily achieved in areas with moderate to high population density and irrigation) were necessary but not sufficient for poverty reduction and food security enhancing growth. As summarised by Djurfeldt et al., 2005), government intervention was needed to promote markets giving smallholder access to and use of available resources and technologies.

Dorward et al. (2004b) therefore proposed a schematic showing the contributions of financial, input and output market interventions in different phases of development (Figure XXX.3). Phase I involves basic investments to establish conditions for new technologies. Uptake is then likely to be limited to a small number of farmers with access to seasonal finance and markets and rapid agricultural transformation needs to be 'kick started' by government interventions (in phase 2 ) enabling larger numbers of farmers to access seasonal finance and seasonal input and output markets at low cost and low risk. Once farmers have become used to the new technologies and when volumes of credit and input demand and of produce supply have built up, transaction costs per unit fall, and are also reduced by growing volumes of non-farm activity arising from growth linkages. Governments can then withdraw from market activities and let the private sector take over (phase 3).

Major difficulties have to be overcome in managing these interventions effectively and efficiently and in resisting political pressures to expand and continue with market interventions and subsidies when they are no longer necessary (and are indeed harmful). There are particular difficulties with timing: the deadweight costs of such interventions are high if they are introduced too early, or continued too long. On the other hand, since they may only yield benefits during a critical but possibly short period in the initial transformation, they may easily be overlooked by analysts. 


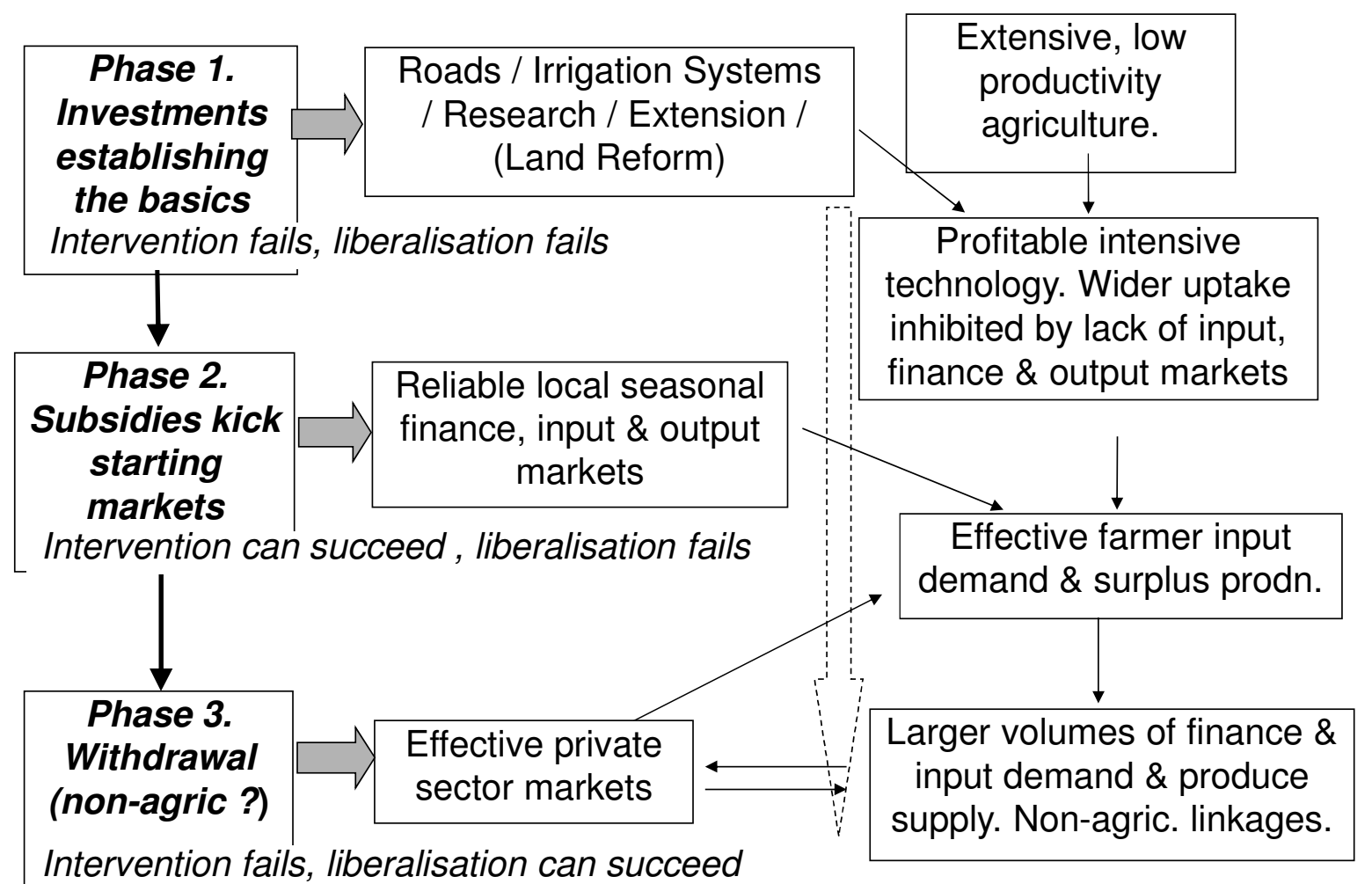

Figure XXX.3 Processes and conditions for agricultural transformations

(adapted from Dorward et al. (2004b)

This analysis, originally put forward in Dorward et al. (2002), was later supported by evidence reported in Fan et al. (2007). The changing pattern of returns to government investment and subsidies presented in figure XXX.2 (with initial high returns to investment, and returns to subsidies rising and then falling ) is remarkably consistent with the phasing of intervention needs and opportunities in figure XXX.3.

The situation in many rain fed areas may be more complicated and challenging than in irrigated areas, and market interventions in the 'kick start phase' may be needed for a longer period at greater expense (Dorward et al., 2004b ). This then increases risks of more entrenched patronage and greater fiscal expenditures. Costs are therefore likely to be higher and implementation more difficult than in irrigated areas in the past.

This analysis leads onto a richer consideration of the possible outcomes from subsidy use. Dorward (2009) drawing on analysis of change in successful Asian Green Revolutions (Rosegrant and Hazell 2000) suggests these outcomes might include

- long term 'thickening' of supply chains and rural input and output markets;

- lower staple food prices and higher wages;

- increased real incomes and food security for both recipients and non-recipients as a result of food price and wage changes; and

- long term economic structural changes, with increased demand for higher value farm and non farm goods and services, together with expanded supply capacity by land and labour released by higher staple crop productivity. 
These augment subsidy benefits identified in more conventional analysis (encouraging farmers' adoption of new technologies) and in arguments for smart subsidies (for example social protection and soil fertility benefits). ${ }^{9}$ They do not, however, negate continuing risks and difficulties- in political diversion, targeting, rationing, control, rent seeking, inefficient management, market distortions, etc.

\section{Heroes, villains or victims?}

This chapter yields a complex picture of the impacts of agricultural subsidies and other forms of agricultural support on food security and poverty reduction. It appears that in their contribution to successful green revolutions in Asia, agricultural subsidies have had hugely beneficial impacts on food security and poverty reduction for billions of people in Asia and, through their impact on global food supplies and prices, around the world. There is, however, also a dark side to agricultural subsidies. This arises with those subsidies in developed economies which depress the earnings and welfare of poor producers and societies in low income countries (cotton subsidies have been perhaps the clearest example). Subsidies can also be used by elites and opportunists in developing countries as channels for stealing government resources - through rents and different forms of 'diversion'. Even well intentioned programmes may be counterproductive if they are implemented without necessary prior and complementary investments and are consequently ineffective, inefficient and a waste of scarce resources. This may also occur if initially successful subsidies are then maintained, and indeed increased, after their usefulness has ended.

The complexity of subsidies' history, characteristics and conflicting political, economic and poverty reduction and food security impacts means, however, that we can also consider subsidies for the poor and food insecure to be 'victims': of their dark side, of their own success (if they are continued after they have become unnecessary and unhelpful), of policy prescriptions where the best is the enemy of the good $^{10}$, and of our lack of understanding of their strengths and weaknesses in different contexts. The results of this are both failures when subsidies are implemented, and failures to implement them when they are needed. This may be an increasingly important issue in the next 50 years as current poverty and food insecurity challenges are exacerbated by dramatically increasing demands for food but increasing threats to its production - from climate change impacts on yields and their stability and from the need to reduce environmentally damaging but yield enhancing agronomic practices. In this context (and with complementary investments in technology, infrastructure and socio-economic change), judicious, differentiated and new uses of subsidies for food production in both developed and developing countries may be crucial in promoting sustainable food security and poverty reduction.

\section{References}

Adams, D. W., Graham, D. \& Pischke, J. D. V. (eds.) 1984. Undermining Rural Development with Cheap Credit., Boulder, Colorado: Westview Press. 
Ariga, J., Jayne, T. \& Nyoro, J. 2008. 2008. Trends and Patterns in Fertilizer Use in Kenya, 1997- 2007. Working Paper. Nairobi: Egerton University, Tegemeo Institute.

Bateman, M. 2012. The Role of Microfinance in Contemporary Rural Development Finance Policy and Practice: Imposing Neoliberalism as 'Best Practice'. Journal of Agrarian Change, 12, 587-600.

Braverman, A. \& Guasch, J. L. 1986. Rural credit markets and institutions in developing countries: lessons for policy analysis from practice and modern theory. World Development, 14, 1253 - 1267.

Chirwa, E. \& Dorward, A. R. 2012 (forthcoming). Agricultural input subsidies in low income coutnries and the Malawi experience Oxford, Oxford University Press.

Crawford, E. W., Jayne, T. S. \& Kelly, V. A. 2006. Alternative approaches for promoting fertilizer use in Africa. Agriculture and Rural Development Discussion Paper 22,. Washington, DC: World Bank.

Djurfeldt, G., Holmen, H., Jirstrom, M. \& Larsson, R. (eds.) 2005. The African Food Crisis: Lessons from the Asian Green Revolution, Wallingford: CABI Publishing.

Dorward, A. R. 2009. Rethinking agricultural input subsidy programmes in developing countries. In: ELBEHRI, A. \& SARRIS, A. (eds.) Non-distorting farm support to enhance global food production. Rome: Food and Agriculture Organisation of the United Nations.

Dorward, A. R. 2012. The short and medium term impacts of rises in staple food prices Food Security, 4, 633-645.

Dorward, A. R. 2013 (forthcoming). Agricultural labour productivity, food prices and sustainable development impacts and indicators. Food Policy.

Dorward, A. R., Fan, S., Kydd, J. G., Lofgren, H., Morrison, J. A., Poulton, C. D., Rao, N., Smith, L. E. D., Tchale, H., Thorat, S., Urey, I. \& Wobst, P. 2004a. Institutions and Economic Policies for Pro-poor Agricultural Growth. IFPRI Discussion paper DSG 15.

Dorward, A. R., Kydd, J. G., Morrison, J. A. \& Urey, I. 2002. A Policy Agenda for Pro-Poor Agricultural Growth. Working paper, Institutions and Economic Policies for Pro Poor Agricultural Growth. Wye: Imperial College London, Department of Agricultural Sciences.

Dorward, A. R., Kydd, J. G., Morrison, J. A. \& Urey, I. 2004b. A Policy Agenda for Pro-Poor Agricultural Growth. World Development, 32, 73-89.

Dorward, A. R., Kydd, J. G., Poulton, C. D. \& Bezemer, D. 2009. Coordination risk and cost impacts on economic development in poor rural areas. Journal of Development Studies, 45.

Druilhe, Z. \& Barreiro-Hurlé, J. 2012. Fertilizer subsidies in sub-Saharan Africa. ESA Working paper No. 12-04. Rome: FAO.

Economist Intelligence Unit 2008. Lifting African and Asian farmers out of poverty: Assessing the investment needs. A custom research project for the Bill and Melinda Gates Foundation. New York The Economist Intelligence Unit.

Eicher, C. K. \& Kupfuma, B. 1998. Zimbabwe's maize revolution: insights for closing Africa's food gap. In: EICHER, C. K. \& STAATZ, J. (eds.) International Agricultural Development. 3rd ed. Baltimore and London: John Hopkins University Press.

Ellis, F. 1992. Agricultural policies in developing countries, Cambridge, Cambridge University Press.

Fan, S., Gulati, A. \& Thorat, S. 2007. Investment, Subsidies, and Pro-Poor Growth in Rural India. IFPRI Discussion Paper 716. Washington D.C.: IFPRI. 
FAO 2003. Trade reforms and food security: conceptualizing the linkages. Rome: FAO.

FAO 2005a. Dairy: measuring the impact of reform FAO Trade Policy Technical Notes on issues related to the WTO negotiations on Agriculture. No. 11. Rome: FAO.

FAO 2005b. Domestic Support: trade related issues and the empirical evidence. . FAO Trade Policy Technical Notes on issues related to the WTO negotiations on Agriculture. No. 5. Rome: FAO.

FAO 2006a. Rice: what do analytical model results tell us? . FAO Trade Policy Technical Notes on issues related to the WTO negotiations on Agriculture. No. 12. Rome: FAO.

FAO 2006b. Trade Policy Simulation Models: Estimating global impacts of agricultural trade policy reform in the Doha Round. FAO Trade Policy Technical Notes on issues related to the WTO negotiations on Agriculture. No. 13. Rome: FAO.

FAO 2011. Agricultural import surges in developing countries: analytical framework and insights from case studies. Rome: FAO.

FAO 2013 (forthcoming). Smallholder integration in changing food markets: implications for policy in support of increased productivity. Rome: FAO.

Financial Times 2011. Farmers' subsidies plunge to 30-year low. 21 Sept 2011. London.

Hazell , P. B. R. 2009. Transforming agriculture: the green revolution in Asia. In: SPIELMAN, D. J. \& PANDYA-LORCH, R. (eds.) Millions fed: proven successes in agricultural devleopment. Washington D.C.: IFPRI.

Helmes, N. \& Lensink, R. 2011. Microfinance: Its Impact, Outreach, and Sustainability. World Development, 39, 875-881.

Hennessy, D. 2004. Measuring the trade distortiveness of domestic policy. Presentation at an Informal Expert Consultation on Domestic Support. FAO, Rome. 30-31 August 2004.

ICTSD 2012. Bridges Weekly Trade News Digest. Volume 16. Number 16. 25 April 2012.

Johnston, B. F. \& Mellor, J. W. 1961. The role of agriculture in economic development. The American Economic Review, 51, 566-593.

Kirsten, J. F. \& van Zyl, J. 1996. The Costs and Benefits of Providing Agricultural Support Services to Rural Households in the Developing Areas of South Africa. Development Southern Africa, 13, 415-28.

Konandreas, P. 2012. World market volatility challenges facing poor net food-importing countries and possible trade policy responses. http://ictsd.org/i/events/dialogues/128643/?view=documentation.

Lipton, M. \& Longhurst, R. 1989. New Seeds and Poor People, London, Routledge.

Matthews, A. 2012. Matthews, A (2012) Latest EU AMS notification confirms declining trend in WTO amber box support. CAP Reform.eu blog (10/4/12)

McCulloch, N., Winters, L. A. \& Cirera, X. 2001. Trade liberalisation and poverty: a handbook, London, Centre for Economic Policy Research.

Mellor, J. W. 1966. The economics of agricultural development, Ithaca, N.Y., Cornell University Press.

Meyer, R. L. 2011. Subsidies as an instrument in agricultural finance: a review. Washington: World Bank.

Morduch, J. 1999. The Microfinance Promise. Journal of Economic Literature, XXXVII, 15691614.

Morris, M. \& Byerlee, D. 1998. Attaining of productivity gains in post green revolution Asian agriculture. In: EICHER, C. K. \& STAATZ, J. (eds.) International Agricultural

Development. 3rd ed. Baltimore and London: John Hopkins University Press. 
Morris, M., Kelly, V. A., Kopicki, R. \& Byerlee, D. 2007. Fertilizer use in African agriculture., Washington D.C., World Bank.

OECD 2004. Risk effects of PSE crop measures. AGR/CA/APM(2002)13/FINAL Paris: OECD.

OECD-FAO (2012) Agricultural Outlook 2012-2021. Paris and Rome.

Piesse, J. \& Thirtle, C. 2009. Three bubbles and a panic: An explanatory review of recent food commodity price events. Food Policy 34, 119-129.

Poulton , C., Dorward, A. \& Kydd, J. 2010. The Future of Small Farms: New Directions for Services, Institutions and Intermediation World Development, 38, 1413-1428.

Rashid, S., Gulati, A. \& Cummings, R. (eds.) 2008. From parastatals to private trade: Lessons from Asian agriculture: John Hopkins University Press.

Rosegrant, M. W. \& Hazell , P. B. R. 2000. Transforming the rural Asian Economy: The Unfinished revolution, Hong Kong, Oxford University Press (China).

Siamwalla, A. \& Valdes, A. 1986. Should Crop Insurance Be Subsidized? In: HAZELL, P., POMAREDA, C. \& VALDES, A. (eds.) Crop insurance for agricultural development : issues and experience. Baltimore: IFPRI / John Hopkins University Press.

Skully, D. 2009. OECD policy and distortionary effects: a review of the evidence. In: ELBEHRI, A. \& SARRIS, A. (eds.) Non-distorting farm support to enhance global food production. Rome: FAO.

Smale, M. \& Jayne, T. 2009. Breeding an 'amizing' crop: improved maize in Kenya, Malawi, Zambia and Zimbabwe. In: SPIELMAN, D. J. \& PANDYA-LORCH, R. (eds.) Millions fed: proven successes in agricultural devleopment. Washington D.C.: IFPRI.

Swinnen, J. 2011. The Right Price of Food. Development Policy Review, 29, 667-688.

Thomas, H. 2006. Trade Reforms and Food Security: country case studies and synthesis. Rome: FAO.

Timmer, C. P. 2010. Reflections on food crises past. Food Policy, 35, 1-11.

Tschirley, D. L. \& Jayne, T. S. 2010. Exploring the Logic Behind Southern Africa's Food Crises. World Development, 38, 76-87.

Von Pischke, J. D., Adams, D. \& Donald, G. (eds.) 1983. Rural Financial Markets in Developing Countries., Baltimore, Md.: Johns Hopkins University Press.

Wiggins, S. \& Brooks, J. 2012. The Use of Input Subsidies in Developing Countries. In: BROOKS, J. (ed.) Agricultural policies for poverty reduction. Paris: OECD.

Williamson, J. 1989. What Washington Means by Policy Reform. In: WILLIAMSON , J. (ed.) Latin American Readjustment: How Much has Happened. Washington: Institute for International Economics

World Bank 1981. Accelerated development in sub Saharan Africa: an agenda for action. Washington D.C.: World Bank.

World Bank 2007. World Development Report 2008: Agriculture for Development. Washington D.C.: World Bank.

\footnotetext{
${ }^{1}$ See Skully (2009 for a more detailed classification of subsidies and explanation of their relative production impacts

${ }^{2}$ Similarly, although the negotiation of multilateral, regional and bilateral trade agreements has also resulted in significant reductions in the average levels of applied agricultural tariffs by both developing and developed countries, averages hide the true picture, with several significant product groups still protected by high, often prohibitive tariffs, preventing access of more competitive imports.
} 
${ }^{3}$ One interesting example of the impact of changing maize prices on returns to producers who have access to a package of policy support measures is illustrated in FAO (2005b).

${ }^{4} \mathrm{FAO}$ (2011) argues that although the incidence of import surges is high, and the impact can be significant, such surges are often the result of factors internal to a country, which limit the capacity of domestic producers to increase production, rather than due to the use of export subsidies by OECD countries.

${ }^{5}$ It is also argued that low agricultural prices have reduced investment in agricultural research, contributing to the slow-down in agricultural productivity growth from the mid 1990s (Piesse and Thirtle, 2009; Timmer, 2010).

${ }^{6}$ In this review we focus on large scale subsidies on staple food crops as they offer wider food security and poverty reduction benefits as compared with agricultural export subsidies (Dorward, 2009). This is not to suggest, however, that the latter cannot offer important but narrower benefits in specific situations.

${ }^{7}$ It is instructive to contrast the focus and findings of these writings with those of Fan et al., 2007 and others who mention state support in the provision of seasonal finance as an important and widespread ingredient in successful agricultural modernisation (e.g. Eicher and Kupfuma, 1998; Kirsten and van Zyl, 1996; Morris and Byerlee, 1998) although some critics did recognise that subsidised credit had worked in some situations (eg Braverman and Guasch, 1986).

${ }^{8}$ This may not be a problem if the providers of land and labour are poor: subsidies may be a way to promote pro-poor growth among poor laborers and land holders. However one may still question if this an efficient or least cost way of making such transfers.

${ }^{9}$ These arguments apply particularly to input subsidies, not price support, price subsidies or credit subsidies: price support harms poor consumers, depresses potential increases in real wages, food security and incomes for poor food buyers, and inhibits growth linkages; price subsidies on staple foods provide benefits to poor food buyers but not to subsistence producers; and particular transaction difficulties with credit for staple food production mean that affordability problems may perhaps be addressed more effectively by high subsidy rates.

${ }^{10}$ This arises where the potential food security and pro-poor growth benefits of subsidies are recognised but their implementation is inhibited by fears that as in much of post green revolution Asia they will later become a major drain on resources. The Asian experience suggests that such fears are overblown - it is better to have the earlier benefits of successful subsidies despite the burden of persistent subsidies than to be denied the initial opportunity of growth. 